\title{
Pemberdayaan masyarakat desa dalam mengelola konflik sosial di Kabupaten Bone
}

\author{
Muh. Iqbal Latief*, Arsyad Genda, Surianto, \& Hariashari Rahim \\ Departemen Sosiologi, FISIP, Universitas Hasanuddin \\ * muhilberkelana@gmail.com
}

\begin{abstract}
Abstrak. Secara umum di Kabupaten Bone telah terjadi konflik yang dilatar belakangi berbagai macam faktor seperti permasalahan tanah, politik bahkan terkait dengan nilai agama dan kepercayaan. Karena itu, tujuan yang ingin dicapai dalam pengabdian ini, untuk meningkatkan pengetahuan dan pemahaman masyarakat desa terhadap potensi konflik dan upaya resolusi konflik yang dilakukan. Metode yang digunakan dalam pelatihan ini adalah pemberian pengetahuan dan pemahaman melalui ceramah dan tanya jawab, praktek melakukan pemetaan potensi konflik Sehingga melalui pelatihan pengelolaan konflik ini akan menghasilkan suatu dokumen pengelolaan konflik. Kegiatan ini dilaksanakan mulai bulan April sampai dengan September 2019 yang dimulai dari perumusan proposal sampai dengan penyusunan laporan akhir kegiatan. Dengan alat yang disiapkan serta merumuskan langkah-langkah pengelolaan konflik yang berpotensi terjadi di masyarakat, maka masyarakat desa sudah mengenal dan memahami pengelolaan konflik dengan sebaik-baiknya.
\end{abstract}

Kata kunci: pemberdayaan, masyarakat desa, mengelola, konflik, Bone

\begin{abstract}
In general, in Bone District there have been conflicts with the background of various factors such as land issues, politics and even those related to religious values and beliefs. Therefore, the goal to be achieved in this service is to increase the knowledge and understanding of the village community on potential conflicts and conflict resolution efforts undertaken. The method used in this training is the provision of knowledge and understanding through lectures and questions and answers, the practice of mapping potential conflicts so that through conflict management training will produce a conflict management document. This activity was carried out from April to September 2019, starting from the formulation of proposals to the preparation of the final activity report. With the tools prepared and formulating conflict management steps that have the potential to occur in the community, the village community will already know and understand conflict management as well as possible.
\end{abstract}

Keywords: empowerment, village community, manage, conflict, Bone

To cite this article: Latief, M. I., A. Genda., Surianto., \& H. Rahim. 2020. Pemberdayaan masyarakat desa dalam mengelola konflik sosial di Kabupaten Bone. Unri Conference Series: Community Engagement 2: 514-521. https://doi.org/10.31258/unricsce.2.514-521

\section{(C) 2020 Authors}

Peer-review under responsibility of the organizing committee of Seminar Nasional Pemberdayaan Masyarakat 2020 


\section{PENDAHULUAN}

Masyarakat dan Bangsa Indonesia lahir melalui proses pembentukan karakter yang kuat dengan melewati beragam fase konflik bahkan pertempuran-pertempuran dahsyat baik pada ketika masa kerajaan nusantara sampai pada masa mempertahankan negara kesatuan Indonesia. Masyarakat dan Bangsa Indonesia dapat berdiri dengan kokoh justru karena adanya kemajemukan dan setiap unsur yang berbeda masing-masing memiliki kesadasan fundamental yang sama tentang pentingnya persatuan dan kesatuan bangsa, pentingnya kedamaian di atas semua kepentingan unsur dan golongan.

Dengan modal kemajemukan tersebut Bangsa Indonesia akan menjadi salah satu bangsa terkuat di dunia selama nilai-nilai kemajemukan tersebut dapat dikelola secara produktif dengan menjunjung tinggi harkat dan martabat kemanusiaan, sebagaimana telah ditegaskan dalam Pancasila sebagai Dasar Negara Indonesia. Sebagai suatu modal maka kemajemukan perlu dirawat sampai pada level masyarakat paling bawah dengan pendekatan yang menyentuh aspek kelembagaannya. Kelembagaan yang paling strategis adalah keluarga khususnya ditingkat rumah tangga karena pada lembaga ini proses sosialisasi dan pendidikan paling pertama dilakukan.

Menurut UU No 6 Tahun 2014 tentang Desa, Kelembagaan Desa teridri ataas: Kepala Desa, Perangkat Desa, Badan Permusyawaratan Desa (BPD). Kelembagaan Desa tersebut memiliki peranan yang sangat penting untuk mendoroong roda pembangunan di wilayahnya. Dalam perkembangan tidak menutup kemungkinan adanya berbagai gejolak dan reaksi dari berbagai pihak baik secara internal maupun secera eksternal. Hal tersebut membutuhkan manajemen untuk pengelolaan konflik sehingga konflik yang terjadi bisa diatasi.

Kabupaten Bone, merupakan salah satu dari 24 kabupaten/kota di Provinsi Sulawesi Selatan dan merupakan kabupaten terbesar penduduknya setelah kota Makassar. Dalam kaitan dengan pengabdian pada masyarakat ini, maka diplih salah satu desa di kabupaten Bone yang memiliki karakteristik tersendiri yaitu desa Passempe Kecamatan Palakka. Karena di desa tersebut, investasi dari luar cukup banyak dan beragam sehingga menimbulkan potensi konflik jika tidak dikelola dengan baik. Untuk jelasnya, dapat dilihat sebagai berikut:

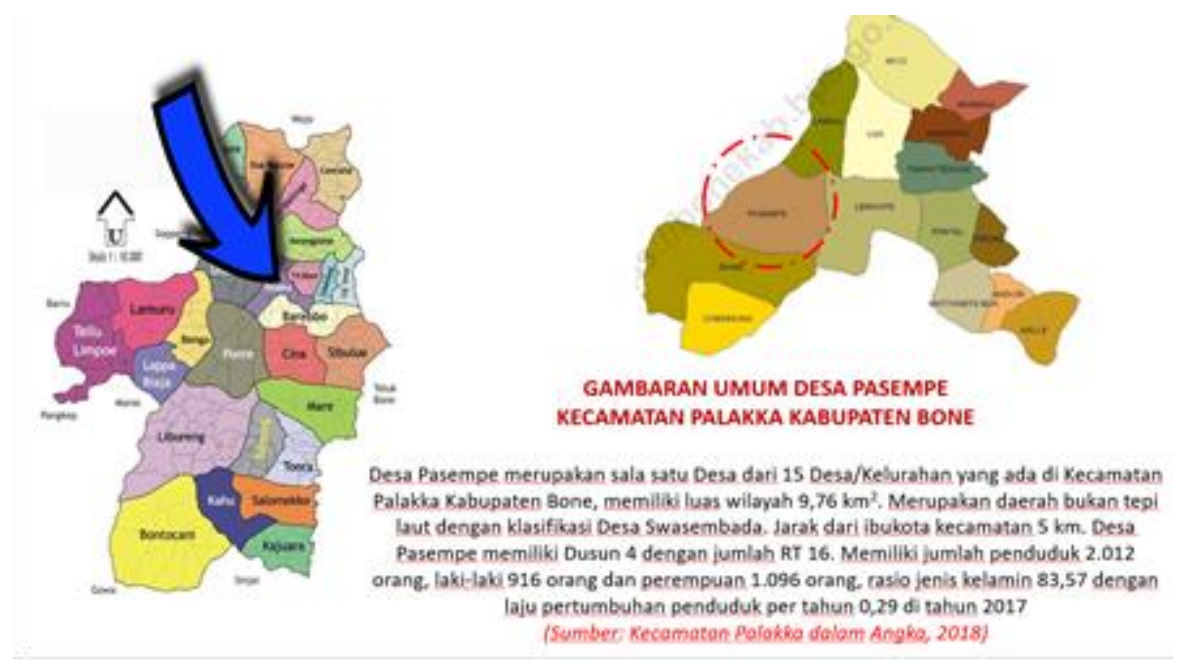

\section{METODE PENERAPAN}

Dalam pelaksanaan kegiatan ini yang merupakan sumber informasi adalah masyarakat sebagai

Subjek bukan sebagai Objek. Prinsip yang dibangun adalah POD (pembelajaran Orang Dewasa) dimana fasilitator bertindak dan mengarahkan jalannya diskusi bukan sebagai sumber belajar akan tetapi bersamasama berdiskusi mememcahkan persolan bersama. Adapun metodologi yang dipakai dalam pelatihan yaitu:

1. FGD/DKT (Focus Group Diskusssion/ Diskusi Kelompok Terarah), dimana peserta terlibat dengan jumlah. 9 - 15 Orang, ada yang bertindak sebagai fasilitator dan notulensi.

2. PRA (Partisipatory Rural Apprasial), dimana yang menjadi penekanan dalam pelatihan ini menggunakan 3 alat kajian utama yaitu: 
a. Matriks Waktu Luang: dalam matriks ini peserta belajar bersama dalam memetakan dan menganalisis waktu luang dalam 1 × 24 jam untuk aktivitas ibu rumah tangga, kegiatan mingguan dan waktu luang yang dapat dipakai dalam kegiatan rembug/musyawarah di Desa Timbuseng.

b. Diagram Venn: dalam diagram ini peserta belajar bersama dalam memetakan kelembagaan/kelompok/perkumpulan/organisasi/sejenisnya, berdasarkan besar dan kecilnya organisasi tersebut, dapat dilihat berdasarkan struktur kepengurusan organisasi, legalitas. Dan hubungan serta manfaat langsung yang dirasakan oleh masyarakat, semakin dekat hubungan kelembagaan/ kelompok/ perkumpulan/ organisasi/ sejenisnya tersebut menunjukkan manfaat langung yang rasakan demikian pula sebaliknya.

c. Matriks Potensi, Masalah dan Alternatif Pemecahan Masalah: dalam matriks ini peserta belajar bersama untuk menemukenali/ menganalisis akar penyebab persoalan konflik yang dihadapi serta memetakan potensi pemecahan masalah serta mencari alternatif pemecahan masalah.

d. Ceramah: dalam kegiatan ini akan diharapakan memberikan informasi kepada peserta terkait penguatan kelembagaan desa untuk deteksi dini untuk pencegahan konflik.

\section{HASIL DAN PEMBAHASAN}

\section{Memahami Konflik}

Pada umumnya konflik diakibatkan oleh perbedaan pendapat, pemikiran, ucapan dan perbuatan. Sikap dasar yang sulit dan tidak ingin menerima dan menghargai perbedaan semacam itu akan mengubah seseorang berwatak berkonflik. Orang seperti ini akan membuat problem kecil dan sederhana sebagai alasan untuk menciptakan konflik. Konflik menjadi saluran dari akumulasi perasaan yang tersembunyi secara terus menerus yang mendorong seseorang untuk berperilaku dan melakukan sesuatu berlawanan dengan orang lain.

Teori konflik dan ideologi Marxin akan tumbuh subur jika adanya kondisi suatu masyarakat yang merasa disubordinat oleh masyarakat lain sehingga memungkinkan terjadinya sebuah konflik untuk saling memperebutkan kekuasaan. Dalam artian bagaimana kelompok yang menjadi subordinat bisa mengambil kekuasaan dari kelompok yang dominan dan cenderung melakukan tindakan destruktif terhadap kelompok subordinat sehingga kelompok itu dapat bebas dari eksploitasi yang cenderung destruktif.

Pandangan Dahrendorf dalam Ritzer, (2003:213) berpendirian bahwa masyarakat mempunyai dua wajah (konflik dan konsensus). Teori konsensus harus meguji nilai integrasi dalam masyarakat dan teori konflik harus menguji konflik dan penggunaan kekerasan yang mengikat masyarakat bersama di hadapan tekanan itu. Dahrendorf mengakui bahwa masyarakat takkan ada tanpa konsensus dan konflik yang menjadi persyaratan satu sama lain. Jadi kita tak akan punya konflik kecuali ada konsensus sebelumnya.

Selain itu pandangan Dahrendorf yang memusatkan perhatian pada struktur sosial yang lebih luas. Inti tesisnya adalah gagsan bahwa berbagai posisi di dalam masyarakat mempunyai kualitas otoritas yang berbeda. Otoritas tidak terletak di dalam masyarakat mempunyai kualitas otoritas yang berbeda . otoritas tidak terletak di dalam diri individu, tetapi di dalam posisi. Dahrendorf tak hanya tertarik pada struktur posisi, tetapi juga konflik antara berbagai struktur posisi itu: "sumber struktur konflik harus dicari di dalam tatanan peran sosial yang berpotensi untuk mendominasi atau ditundukkan". Menurut Dahrendorf, tugas pertama analisis konflik adalah mengidentifkasi berbagai peran otoritas di dalam masyarakat. Karena memusatkan perhatian pada struktur bersakala luas seperti peran otoritas itu.

Otoritas dalam setiap asosiasi bersifat dikotomi, karena itu hanya ada dua, kelompok konflik yang dapat terbentuk di dalam setiap asosiasi. Kelompok yang memegang posisi otoritas dan kelompok subordinat yang mempunyai kepentingan tertentu "yang arah dan substansinya saling bertentangan". Di sini kita berhadapan dengan konsep kunci lain dalam teori konflik Dahrendorf, yakni kepentingan. Kelompok yang berada diatas dan yang berada di bawah didefinisikan berdasarkan kepentingan bersama. Dahrendorf tetap menyatakan bahwa kepentingan itu, yang sepertinya tampak sebagai fenomena psikologis, pada dasarnya adalah fenomena bersakala luas.

Pemikiran awal tentang fungsi konflik sosial berasal dari Georg Simmel, tetapi diperluas oleh Coser (Ritzer, 2003:159) yang menyatakan bahwa konflik dapat membantu mengeratkan ikatan kelompok yang berstruktur secara longgar. Masyarakat yang mengalami disintegrasi, atau berkonflik dengan masyarakat lain, dapat memperbaiki kepaduan integrasi. 
Ada beberapa metode/cara yang dapat menjadi alternatif untuk menyelesaikan suatu konflik diantaranya adalah:

a. Dengan melakukan pendekatan. Sudah menjadi kebiasaan khas dalam konflik adalah memberikan prioritas yang tinggi guna mempertahankan kepentingan pihaknya sendiri, sehingga jika kepentingan A bertentangan dengan kepentingan $\mathrm{B}$, maka A cenderung mengabaikan $\mathrm{B}$, atau secara aktif menghancurkannya. Pendekatan disini dibedakan oleh apakah perhatian bagi diri sendiri atau perhatian bagi orang lain itu tinggi atau rendah.

b. Dengan mengalah. Ini mengimplikasikan perhatian yang lebih terhadap kepentingan pihak lain kepentingan diri sendiri.

c. Menghindari konflik dan mengundurkan diri. Ini menunjukkan kepedulian yang rendah pada diri sendiri dan pihak lain.

d. Mencari kompromi dan mencoba mengakomodasikan kepentingan kedua belah pihak. Ini lebih menyeimbangkan perhatian pada diri sendiri dan pihak lain.

e. Memberi penghargaan yang tinggi bagi kepentingan diri sendiri dan pihak lain. Ini mengimplikasikan penegasan yang kuat terhadap kepentingan sendiri, tetapi juga menyadari aspirasi dan kebutuhan pihak lain, berusaha untuk mencari hasil penyelesaian masalah yang kreatif.

f. Dalam konflik yang strukturnya tidak simetris, yang kuat selalu menang dan yang lemah selalu kalah. Satu-satunya cara untuk menyelesaikan konflik jenis ini adalah dengan mengubah strukturnya, tetapi ini merupakan keinginan dari pihak yang kuat. Sehingga di sini tidak ada hasil menang-menang, jadi pihak ketiga harus menggabungkan kekuatan dengan pihak yang lemah untuk menghasilkan pemecahan

\section{Mengelola Potensi Konflik}

Pendekatan kelembagaan merupakan salah satu bentuk pendekatan yang akan didorong dan difasilitasi melalui pelatihan khususnya pada kegiatan pengabdian masyarakat yang dilaksanakan di Kabupaten Bone. Pemilihan dan penetuan lokasi didasarkan pada salah satu pertimbangan bahwa di daerah tersebut telah terjadi beberapa konflik baik vertikal maupun horisontal. Secara umum gambaran konflik yang pernah terjadi di Kabupaten Bone berdasarkan hasil pemetaan daerah rawan konflik di Sulawesi Selatan khususnya di Kabupaten Bone yang dilaksanakan oleh Dinas Sosial Provinsi Sulawesi Selatan Tahun 2014 sebagai berikut:

Tabel 1. Beberapa Isu Konflik di Kabupaten BoneTahun 2014

\begin{tabular}{|c|c|c|c|c|c|}
\hline No & Isu Konflik & Lokasi Konflik & $\begin{array}{l}\text { Luas Area } \\
\text { Sengketa }\end{array}$ & $\begin{array}{c}\text { Pihak-pihak yang } \\
\text { Terlibat }\end{array}$ & Deskripsi Konflik \\
\hline 1 & Lahan Hutan & $\begin{array}{l}\text { Desa Tapong } \\
\text { Kecamatan } \\
\text { Tellu Limpoe } \\
\text { Kabupaten } \\
\text { Bone dan } \\
\text { Desa Bacu- } \\
\text { bacu } \\
\text { Kabupaten } \\
\text { Barru. }\end{array}$ & $\begin{array}{l}\text { Lahan Hutan } \\
\text { Lindung }\end{array}$ & $\begin{array}{l}\text { Masyarakat Desa } \\
\text { Tapong } \\
\text { Kecamatan Tellu } \\
\text { Limpoe } \\
\text { Kabupaten Bone } \\
\text { Dan } \\
\text { Desa Bacu-bacu } \\
\text { Kabupaten } \\
\text { Barru. }\end{array}$ & $\begin{array}{l}\text { Adanya perambahan hutan } \\
\text { dengan menebang pohon hutan } \\
\text { lindung. Lahan tersebut } \\
\text { merupakan sumber mata air. } \\
\text { Adanya pembiaran yang } \\
\text { dilakukan oleh aparat masing- } \\
\text { masing. Adanya saling } \\
\text { mengklaim batas-batas wilayah } \\
\text { dengan cara warga yang masuk } \\
\text { dari barru dengan informasi } \\
\text { dari warga bone begitupun } \\
\text { sebaliknya. Masyarakat kurang } \\
\text { dilibatkan yang hanya terlibat } \\
\text { adalah oknum dari aparat } \\
\text { pemerintah setempat. } \\
\text { Penduduk Desa Tapong } \\
\text { dengan jumlah } 1.318 \text { orang, } \\
\text { laki-laki } 674 \text { orang dan } \\
\text { perempuan } 644 \text { orang.Kondisi } \\
\text { sekarang berpenghuni sekitar } \\
40 \text { tempat hunian. Sudah ada } \\
\text { yang memperjual belikan } \\
\text { dengan harga } 5 \text { juta dengan }\end{array}$ \\
\hline
\end{tabular}


ukuran 15 x $20 \mathrm{~m}$.

\begin{tabular}{|c|c|c|c|c|c|}
\hline 2 & $\begin{array}{l}\text { Perang Antar } \\
\text { Kelompok }\end{array}$ & & & $\begin{array}{l}\text { Kelompok } \\
\text { Labempa dan } \\
\text { Lacokkong } \\
\end{array}$ & \\
\hline 3 & $\begin{array}{l}\text { Konflik } \\
\text { Kampus STAI } \\
\text { Al Gazali } \\
\text { Bone }\end{array}$ & $\begin{array}{l}\text { Kec. Tanete } \\
\text { Riattang Kab. } \\
\text { Bone }\end{array}$ & & $\begin{array}{l}\text { Mahasiswa dan } \\
\text { Yayasan }\end{array}$ & $\begin{array}{l}\text { Mahasiswa menuntuk hak- } \\
\text { haknya seperti sistem anggaran } \\
\text { dan fasilitas kampus kepada } \\
\text { pihak kampus agar proses } \\
\text { perkulihan bisa berjalan } \\
\text { efektif. Ini beraikibat } \\
\text { penyegelan kampus. } \\
\end{array}$ \\
\hline 4 & $\begin{array}{l}\text { Tapal batas } \\
\text { Desa }\end{array}$ & $\begin{array}{l}\text { Tapal batas } \\
\text { Desa Sailong } \\
\text { dengan Desa } \\
\text { Sanrangeng } \\
\text { Kec. Dua } \\
\text { Boccoe Kab. } \\
\text { Bone } \\
\end{array}$ & & $\begin{array}{l}\text { Masyarakat Desa } \\
\text { Sailong dengan } \\
\text { Desa Sanrangeng } \\
\text { Kec. Dua Boccoe } \\
\text { Kab. Bone }\end{array}$ & $\begin{array}{l}\text { Perkelahian Kelompok tentang } \\
\text { batas wilayah }\end{array}$ \\
\hline 5 & $\begin{array}{l}\text { Konflik } \\
\text { Lahan }\end{array}$ & $\begin{array}{l}\text { Dusun } \\
\text { Calengke } \\
\text { Desa } \\
\text { Patimpeng } \\
\text { Kec. } \\
\text { Patimpeng, } \\
\text { Desa } \\
\text { Gattareng } \\
\text { Kec. Kahu, } \\
\text { Dusun } \\
\text { Labombo } \\
\text { Desa } \\
\text { Wanuawaru } \\
\text { Kec. } \\
\text { Libureng dan } \\
\text { Dusun } \\
\text { Lassengkong } \\
\text { Desa Bune } \\
\text { Kec.Libureng }\end{array}$ & $\begin{array}{l}3 \text { ha, } 12 \text { ha, } 14 \\
\text { ha, } 8 \text { ha, dan } 200 \\
\text { ha }\end{array}$ & $\begin{array}{l}\text { Masyarakat dan PT. } \\
\text { PTPN X PGB } \\
\text { Arasoe/PT. PTPN } \\
\text { X PGB Camming }\end{array}$ & $\begin{array}{l}\text { Sengketa lahan dipabrik gula: PT. } \\
\text { PTPN X PGB Arasoe/PT. PTPN X } \\
\text { PGB Camming dengan masyarakat } \\
\text { yang berdampak pada konflik } \\
\text { horizontal antara masyarakat } \\
\text { dengan pihak perusahaan, } \\
\text { penyanderaan barang-barang } \\
\text { perusahaan, blockade jalan dan } \\
\text { pengrusakan kantor dan alat } \\
\text { perusahaan }\end{array}$ \\
\hline 6 & $\begin{array}{l}\text { Perkelahian } \\
\text { Kelompok }\end{array}$ & Kab Bone & & Pemuda & $\begin{array}{l}\text { Perselisihan antara pemuda Bene } \\
\text { dan Lonrae Kec. T. R. Timur Kab. } \\
\text { Bone dan perselisihan antara } \\
\text { kelompok pemuda kampung leteng } \\
\text { dengan kampung bajo dan } \\
\text { perselisihan antara kelompok } \\
\text { Labempa dan Lacokkong }\end{array}$ \\
\hline 7 & Terorisme & Kab. Bone & & $\begin{array}{l}\text { Masyarakat dan } \\
\text { Aparat Kepolisian }\end{array}$ & $\begin{array}{l}\text { Dugaan keberadaan DPO teroris } \\
\text { an. Hamdara Tahmil di Kab. Bone } \\
\text { yang berakibat pada aksi main } \\
\text { hakim sendiri oleh masyarakat. } \\
\text { Rekruitmen anggota teroris dan } \\
\text { Aksi terror dari DPO tersebut. }\end{array}$ \\
\hline
\end{tabular}

Sumber: Data Dinas Sosial Provinsi Sulawesi Selatan Tahun 2014

Berdasarkan data tersebut bahwa masalah tanah/agraria merupkan salah satu isu yang dapat memicu terjadinya konflik sosial di masyarakat. Beberapa permasalahan agraria/tanah yang dapat menimbulkan konflik seperti pembukaan lahan perkebunan terutama yang dilakukan oleh pihak pemerintah atau swasta, 
penyerobotan tanah serta permasalahan tanah warisan. Isu yang lain adalah terkait dengan permasalahan politik sehingga hampir semua level pemilihan seperti pemilihan Bupati dan Kepala Desa cendrung menimbulkan konflik antar warga bahkan sesama anggota keluarga. Sikap dan pilihan politik yang tidak diikuti dengan pemahaman nilai-nilai demokrasi yang baik dan benar merupakan fakto pemicu terjadinya konflik. Permasalahan lain yang sangat berpotensi menimbulkan konflik adalah penyebaran nilai-nilai ajaran baru dalam agama yang dianggap bertentangan atau tidak sesuai dengan apa yang telah diyakini dan dilakukan oleh masyarakat selama ini.

Terkait dengan hal di atas, secara fungsional, konflik dipandang memiliki fungsi sosial yang positif seperti pendangan George Simmel dan Lewis Coser. Sementara Marx dan Ibu Khaldun memandang bahwa konflik menjadi dinamika sejarah manusia. Lain halnya dengan Max Weber dan Dahrendorf yang memandang konflik sebagai entitas hubungan sosial. Demikian pula dengan Maslow, Max Neef, John Burton dan Marshal Rosenberg yang memandang konflik sebagai bagian dari proses pemenuhan kebutuhan dasar manusia. Sementara itu, Poerwadarminta dalam Kamus Umum Bahasa Indonesia (1976) menyebutkan bahwa konflik berarti pertentangan atau percekcokan. Pertentangan bisa dalam bentuk ide maupun fisik antara dua belah pihak yang berseberangan.

Dalam studinya, Saefullah (2003:154) membagi jenis dan bentuk insiden kekerasan keagamaan degan berbagai kategori, yaitu; dari segi jenisnya, insiden kekerasan terkait konflik keagamaan dibagi menjadi:

1. Penyerangan terhadap orang/kelompok orang

2. Penyerangan terhadap properti milik orang/kelompok orang

3. Penyerangan terhadap aparat pemerintah/properti milik pemerintah

4. Penyerangan terhadap warga asing/properti milik pemerintah asing

5. Bentrok antara warga/kelompok keagamaan vs aparat keamanan

6. Bentrok antarakelompok warga, dan

7. Kerusuhan/amuk massa berdampak pada korban jiwa/kerusakan properti milik kelompok keagamaan.

Adapun dari segi bentuknya, kekerasan/penyerangan dikelompokkan menjadi:

1. Penyisiran/pengusiran

2. Penyanderaan/penculikan/penahanan

3. Penganiyaan

4. Penganiyaan hingga tewas

5. Penembakan/pembunuhan

6. Penyitaan/penyegelan

7. Perusakan

8. Perusakan disertai penjarahan/pembakaran

9. Pengeboman

10.Penganiayaan/pembunuhan disertai perusakan/pembakaran 


\section{Penguatan kelembagaan desa untuk pemberdayaan masyarakat}

Karakteristik kelembagaan desa di desa Passampe kecamatan Palakka, tergambar sebagai berikut :

Kelembagaan/kelompok/perkumpulan/organisasi/sejenisnva di Desa Pasempe Kecamatan Palakka

Kabupaten Bone yang diurutkan menurut besar kecilnva kelembagaan antara lain sebagai berikut:

\begin{tabular}{|c|c|c|}
\hline No. & $\begin{array}{c}\text { Kelembagaan/ Kelompok/ } \\
\text { Perkumpulan/ Organisasi/ } \\
\text { Sejenisnya }\end{array}$ & Kegiatan \\
\hline 1. & BPD & $\begin{array}{l}\text { Badan Permusyawaratan Desa } \\
\text { merupakan lembaga musyawarah di } \\
\text { tingkat Desa untuk pengambil } \\
\text { kebijakan dengan melibatkan Kepala } \\
\text { Desa dan LPM }\end{array}$ \\
\hline 2. & LPM & $\begin{array}{l}\text { Lembaga Pemberdayaan Masyarakat } \\
\text { merupakan lembaga untuk mendorong } \\
\text { partisipasi masyarakat }\end{array}$ \\
\hline 3. & Karang Taruna & Merupakan lembaga kepemudaan \\
\hline 4. & BUMDES & Badan Usaha Milik Desa \\
\hline 5. & PKK & $\begin{array}{l}\text { Pemberdayaan Kesejahteraan } \\
\text { Keluarga }\end{array}$ \\
\hline 6. & Majelis Taklim/ Pengajian & $\begin{array}{l}\text { Kelompok sosial kemasyarakatan di } \\
\text { bidang agama }\end{array}$ \\
\hline 7. & Kader & $\begin{array}{l}\text { Kelompok yang bergerak dibidang } \\
\text { Kesehatan/ Posyandu/ PKK }\end{array}$ \\
\hline 8. & Lansia & Kelompok Lansis \\
\hline 9. & PEKKA & $\begin{array}{l}\text { Kelompok Perempuan Kepala } \\
\text { Kelaurga }\end{array}$ \\
\hline 10. & PKH & Kelompok Program Keluarga Harapan \\
\hline
\end{tabular}

DIAGRAM VENN/ KAJIAN KELEMBAGAAN

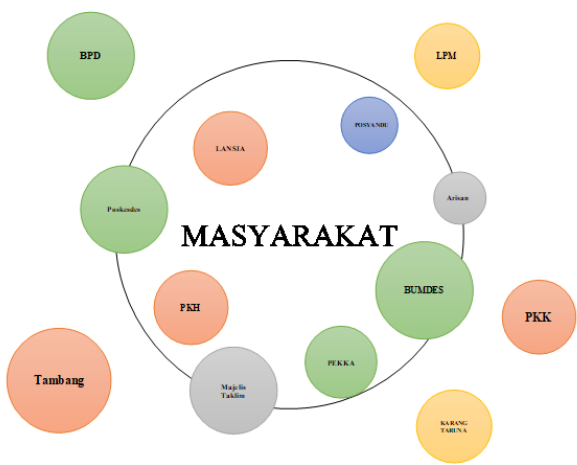

\section{Analisis kelembagaan}

Hasil menunjukkan bahwa eksistensi Lembaga dalam pengelolaan konflik belum signifikan karena banyaknya Lembaga/kelompok yang ada di Desa Pasempe Kecamatan Palakka Kabupaten Bone dibentuk hanya berdasarkan kebutuhan program, belum pada taraf Institusionalized dan internalisasi. Institusionalized berarti Lembaga sudah diakui keberadaannya oleh masyarakat dan menunjukkan eksistensi berdasarkan kebutuhan arus dari bawah (masyarakat). Internalisasi berarti dalam Lembaga tersebut sudah penanaman nilai dan norma yang dijadiakan rujukan bersama dalam pengelolaan konflik.

Oleh karena itu untuk mencegah potensi konflik yang mungkin terjadi dan menyelesaikan permasalahan yang ada maka kelembagaan yang telah dianggap berfungsi baik dalam masyarakat perlu dioptimalkan, sementara yang belum optimal dianggap perlu untuk dilakukan revitalisasi atau penguatan kembali fungsi kelembagaan dapat berkelanjutan

\section{Pemetaan masalah dan potensi pengelolaan konflik}

\section{Masalah}

Dari hasil FGD (Focus Group Discussion), diperoleh gambaran bahwa masalah dan potensi konflik masih tampak dalam masyarakat desa, disebabkan:

1. Penerima kartu KIP, KIS belum tepat sasaran, masyarakat menganggap bahwa Kartu Indonesia Pintar dan Kartu Indonesia Sejahtera diberikan kepada orang yang tidak berhak.

2. Kebutuhan Pupuk untuk petani belum tercukupi, tidak sesuai antara permintaan masyarakat dengan ketersediaan pupuk dari pemerintah

3. Masyarakat mudah menerima informasi yang bersifat Hoax dari Media Sosial

4. Rencana pembangunan tambang kapur, dari hasil diskusi menunjukkan bahwa belum ada kesepahaman antara pihak pemerintah Desa, Masyarakat dan Pihak dari perusahaan serta unsur pemegang kebijakan terkait pemberian Izin Pengelolaan tambang. Masyarakat khawatir jika tambang tersebut ada maka bisa merusak potensi SDA/Mata Air yang ada di area pegunungan. Hal ini sudah dilaporkan kepada pihak berwajib untuk menangani hal tersebut.

\section{Potensi}

1. Masyarakat masih menjunjung tinggi semangat persatuan dan kesatuan, dibuktikan dengan masih mudah penggalangan kegiatan hari-hari besar.

2. Gotong Royong, jika sanak saudara/family melakukan hajatan maka seluruh warga masyarakat tolongmenolong dalama kegiatan tersebut. 
3. Masyarakat masih menjunjung tinggi nilai adat istiadat yang berlaku dalam masyarakat. Desa ini mayoritas dihuni dan pada umumnya di Kabupatan Bone merupakan daerah Kerajaan yang tentunya didalamnya ada bangsawan.

\section{KESIMPULAN}

Dari pemaparan di atas, kesimpulan dari tulisan ini ialah untuk mencegah potensi konflik yang mungkin terjadi dan menyelesaikan permasalahan yang ada maka kelembagaan yang telah dianggap berfungsi baik dalam masyarakat perlu dioptimalkan, sementara yang belum optimal dianggap perlu untuk dilakukan revitalisasi atau penguatan kembali fungsi kelembagaan dapat berkelanjutan; Masyarakat beserta stakeholder secara arif dan bijaksana dalam memahami setiap gejala permasalahan yang muncul sehingga potensi konflik yang berujung kepada kekerasan dapat dideteksi sedini mungkin. Dan; Penguatan Modal Sosial termasuk Nilai-nilai kearifan lokal yang sudah ada dalam masyarakat.

\section{DAFTAR PUSTAKA}

Horton, Paul B dan Hunt, Chester L. 1993. Sosiologi. Edisi keenam. Jilid 1. Jakarta: Erlangga.

Nasikun, DR. 2005. Sistem Sosial Indonesia. PT. RajaGrafindo Persada. Jakarta.

Radjab, Mansyur, dkk. 2015. Pelatihan Pemetaan Partisipatif: Sebagai Upaya Komunitas Petani Dalam Mengidentifikasi Permasalahan Produksi Rumput Laut di Desa Baruga Kecamatan Pajukukang Kabupaten Bantaeng. (Laporan Hasil Pengabdian Masyarakat). LP2M Unhas.

Saefullah, Budi Yana. 2003. Modul Pelatihan Pengorganisasi Masyarakat. Institute For Civil Society (INCIS). Jakarta

Data Dinas Sosial Provinsi Sulawesi Selatan Tahun 2014 